\title{
Legal Protection of Women's Equal Right to Employment
}

\author{
Kexin $\operatorname{Sun}^{1, *}$ \\ ${ }^{1}$ Fujian Police College, Execution Department, Fuzhou China, 350000 \\ *Corresponding author. Email: skx888@163.com
}

\begin{abstract}
Equality is the ultimate goal of human history and equality between the sexes is the common pursuit of all peoples in the world. Women's equal employment status is to some extent a mirror of a country's level of human rights development and implementation. In recent years, gender discrimination has become the main problem of employment for women and the unequal treatment of women in employment has occurred frequently in the world, such as employment discrimination, occupational discrimination or wage discrimination. Although international conventions, as well as laws and regulations of various countries clearly stipulate that employing units may not discriminate against workers on the basis of sex, due to the fact that the content of the legal system has not yet been concretely improved and the relevant departments have not strictly investigated and dealt with it, gender discrimination in employment still exists. This paper mainly uses comparative analysis to study the international law stipulation in the anti-employment sex discrimination and analyze the problems of each country's present anti-employment sex discrimination law, this paper also puts forward some legislative and judicial suggestions on anti-employment discrimination for future progress.
\end{abstract}

Keywords: women, equality, employment discrimination, women's equal right to employment.

\section{INTRODUCTION}

At present, women's employment discrimination is still a prominent issue. In the era of globalization in which employment equality has become a universal value, how to form a sound and complete legal guarantee system against employment discrimination has become an urgent issue.

In many countries, female's equal right in employment is protected in the constitution. With the development of equality movement, there are more and more cases concerning equal employment rights for women, which has played a positive role in the constitutional protection of women's right. Through the collation of the present research situation abroad, it can be found that even though the national conditions vary from country to country and the frequency and importance of each law are not the same, the basic guarantee of women's equal right to employment mainly take the constitution as the most standard legal protection way, secondly echo with the related law again. However, in the process of dealing with practical problems, the problems are mostly the same, mainly existing in the definition of the concept of discrimination, the way of relief and the proof. This is also a gap in the current research on anti-discrimination against women in employment.

Based on the ideas of finding, analyzing and solving problems and through the methods of literature research and comparative research, this paper puts forward some suggestions to solve the discrimination of women in employment.

\section{ANALYSIS ON GENDER DISCRIMINATION}

\subsection{Theories related to gender discrimination in employment}

A study by Stelle James (1975) estimated that the annual loss in GDP due to sex discrimination was about 3\%. Gender-related discrimination called "Sexism", which relates to discrimination and prejudice due to one's biological or social sex [1]. This term first appeared in the United States in the 1960s which is used to describe all manner and behavior that discriminate against women in life. In The Convention on the Elimination of All Forms of Discrimination against Women, the term 


\begin{abstract}
"Discrimination against women" is more clearly defined as any distinction, exclusion or restriction based on sex which has the effect or purpose of impairing or nullifying the recognition, enjoyment or exercise by women, whether or not married, of their human rights and fundamental freedoms in the political, economic, social, cultural, civil or any other field on the basis of equality between men and women.
\end{abstract}

\subsection{Forms of discrimination}

\subsubsection{Employment discrimination}

Employment discrimination can take three forms: difference, rejection, or special treatment. "Difference" refers to unequal treatment in view of gender, such as increasing female entry requirements. "Rejection" refers to the employer's refusal to hire female job applicants or refuses to give female workers equal treatment at work. "Special treatment" refers to special treatment on the basis of gender, such as having priority to the employment of men in the job search process or giving priority to the promotion of men's job status [1].

\subsubsection{Occupational discrimination}

Employed women are often placed in less important, less technical, and lower-paid jobs ---so called "Threeplus-three-less" jobs for women: more fake jobs with fewer real jobs, more supporting roles with fewer leading roles, and more deputy positions with fewer full-time jobs. Therefore, the "Sex segregation" forms in the workplace [2]. Once women are faced with maternity leave, breast-feeding leave and so on, the performance appraisal indicators will be low which will have a negative impact on the promotion of women.

\subsubsection{Wage discrimination}

Income is also an important measure of the occupational status of both sexes. The income ratio between men and women is a direct indicator of discrimination against women in the occupational field. Statistics for 2007 show that the Nordic countries have the smallest income gap between men and women, with countries such as Sweden, Norway and Finland having an income ratio of $100: 84$, or $84 \%$ of men's income. China, the United States, Russia and other countries are in the middle, at $65.5 \%$. India is at the bottom, where women make up only $38 \%$ of men's income [3, 4]. It is a selfevident fact that men's wages are higher than women's under the same circumstances and there is a huge gap in wages between sexs.

\subsection{Legal system of eliminating employment discrimination}

\subsubsection{Universal Declaration of Human Rights}

Internationally, the earliest record of the right to equal employment can be traced back to the adoption of the Universal Declaration of Human Rights by the United Nations General Assembly in 1948. Article 23 of the Declaration provides that every citizen has the right to work, to freely choose his or her occupation and to protect themselves against unemployment. In addition, Article 23 paragraph 1 of the Declaration specifies the right to work, the right to employment, and the right to Equal Pay Day [5].

\subsubsection{International Covenant on Economic, Social and Cultural Rights}

The International Covenant on Economic, Social and Cultural Rights affirms the equal economic, social and cultural rights of men and women. Article 7 of the Convention makes explicit provision for equality between men and women in employment, guaranteeing women working conditions not less favorable than those enjoyed by men and the right to Equal Pay Day [5].

\subsubsection{The Convention on the Elimination of All Forms of Discrimination against Women}

The Convention on the Elimination of All Forms of Discrimination against Women is regarded as the "International Charter of Women's rights". It is an important international human rights convention specially formulated by the United Nations to eliminate discrimination against women and strive for gender equality. The convention stipulates that proper legislation and other measures, including severe sanctions, should be adopted to prohibit all discrimination against women [6].

\subsubsection{International Labor Organization's non- discriminatory standards}

The first international labor standards directly applicable to women were formally adopted by the International Labor Organization (ILO) at its first meeting in 1919. At that meeting, the International Labor Organization had taken into account the Convention on the protection of pregnant women and the Convention on night work, which had originally been designed to protect and preserve the family and social roles of women [7]. Equal Remuneration Convention was also drafted at the thirty-fifth session of the International Labor Conference in 1995. "Equal Pay Day" means equal pay for work of equal value, regardless of the sex of the worker [8]. Equal Pay Day is one of the core conventions of the ILO and plays an extremely important role in prohibiting and 
eliminating gender discrimination in the field of occupation.

\section{SHORTCOMINGS OF CURRENT ANTI- EMPLOYMENT DISCRIMINATION LAW}

Fawcett (1918) put forward the concept of "Equal Pay Day" which is to demand equal employment opportunities, advocating the protection of women and men's fair competition [5]. Equal Pay Act plays a vital role in reducing wage discrimination. However, it did not explain how to eliminate gender discrimination in employment and occupation.

At present, many countries have not enacted special laws and legal provisions for the protection of women's rights or interests and the legal system about this is scattered which has not formed an organic unified system. In many countries, the current legislation on women's right to equal employment is mostly in principle. First, the definition of gender discrimination in employment is not clear which results that it is difficult to prove through the courts that women have been discriminated against. Second, in terms of gender discrimination in employment, the current law lacks the operability to determine gender discrimination in employment. Finally, with regard to legal liability, the existing provisions are too general and simple, with neither a clear definition of responsibility nor a specific implementing organ [9]. Therefore, such a law would have neither a deterrent effect nor the legislative objective of protecting women's right to equal employment.

\section{FURTHER LEGISLATIVE PROPOSALS}

\subsection{Establish a special independent equal employment commission}

From the legislative practice of various countries or regions, the role of the establishment of an Equal Opportunities Commission is very important. Many countries or regions also have this kind of institution against gender discrimination in employment. For example, the Equal Employment Opportunity Commission (EEOC) in the United States, the EEOC in the United Kingdom and the EEOC in Hong Kong all play a pivotal role in ensuring women's equal employment rights. In line with the practice of national enforcement and enforcement agencies of equal employment laws for women, such agencies should have the following characteristics and functions. First, the institution shall be composed of professionals, among whom, in addition to government personnel, the government shall also appoint relevant labor law experts and scholars, as well as some units, trade unions or organizations. Because of the complexity of gender discrimination cases, and in particular the complexity of the criteria for identifying various discriminatory acts, it is important that the personnel dealing with the issue be of professional quality and professionalism. Secondly, it will play an important role in law enforcement. It can not only bring lawsuits on behalf of discriminated individuals in major cases, but also has the right to identify and punish employers for discriminatory practices. It also has the right to issue "non-discrimination notices", which means that the Equal Opportunities Commission can enforce the notices through civil courts, follow up the court litigation, conduct investigations, provide advisory opinions to the government and take actions to educate and persuade public opinion.

\subsection{Refine and improve relevant laws and regulations}

The existing legal provisions on employment discrimination are relatively scattered and countries should improve them on the basis of the existing laws and regulations in accordance with their national conditions. First of all, in the formulation of legal provisions, countries should clearly define the specific definition of gender discrimination in employment. All countries should also broaden the scope of gender-based employment discrimination and ensure that it does not occur at all stages of employment. Secondly, most of the discrimination provided for in the existing laws is direct discrimination and there is no corresponding provision for those hidden acts that have substantial discriminatory consequences for a given sex. Because indirect discrimination is difficult to distinguish and the identification standard is complex and more covert, under normal circumstances, employers generally use indirect discrimination [10]. Thus, indirect discrimination is more common in our daily life. Therefore, each country's law should incorporate the indirect discrimination behavior into the legal regulation, provides the concrete cognizance standard. In conclusion, in the future legislative process, each country should explicitly prohibit gender-based employment, occupational, and wage discrimination.

\subsection{Improve the court trial system and increase the intensity of punishment}

In practice, compared with the employing units, female job seekers are generally in a weak position and the employing units are easy to cover up their discrimination with other plausible reasons. Countries should draw on successful experiences, such as the EU member states' legislation that shifts the burden of proof to the respondent employer when the plaintiff has established de facto discrimination. Because from a practical point of view, it is difficult for workers to collect the relevant evidence of being discriminated against, thus bearing the risk of losing the case. If the employing units bear the burden of proof, they need to provide effective 
evidence to prove the rationality of their behavior. If the employing unit has no way to prove the rationality of its behavior, the employer can be presumed to discriminate against the worker. Such rules of proof can increase the cost of employing units to carry out discriminatory acts and increase the enthusiasm of workers to seek legal redress when they are discriminated against, which are more conducive to the realization of women's equality employment. In addition, since the execution is mainly the responsibility of the court, the court's trial team should increase the proportion of women. If it is determined that there is unfair discrimination in the case, the court can order the determination of the rights of the parties, recommend litigation procedures and award damages [11]. In addition, anti-employment discrimination laws should make a clear distinction between the stages of conduct of a person who discriminates, taking into account the stages of his or her violation, so as to make him or her more willing to suspend the act of discrimination automatically at an early stage, rather than encouraging expose fact to enforcement measures. It makes possibilities to consider the demand of employing agencies which will promote their compliance with the relevant laws and regulations.

\section{CONCLUSION}

In recent years, sex discrimination as a common form of discrimination has been widely concerned. Defining the concept of gender discrimination, formulating clear laws and adequate remedies to eliminate gender discrimination have become a major issue in the field of legal research. The lively discussion of discrimination in recent years is the improvement of people's awareness of their rights. The process of striving for gender equality has been synchronized with the constitutional development of each country and the provisions on gender equality in the constitution reflect the degree of democracy and progress in the country. Women's equal right to employment are also stipulated in various international conventions. These provisions have played a significant role in the subsequent enactment of laws specifically designed to protect women's right to equal employment.

From the perspective of legislation and practice, the specific legislation on sex discrimination in employment has not been fully enacted and implemented, and the penalties imposed on the units and individuals responsible for such discrimination have not been sufficiently severe. Also, the enforcement environment and supporting measures remain inadequate. Starting from the definition of employment discrimination, by combing the causes of its formation and the status quo of anti-employment discrimination law, this paper puts forward the assumption of perfecting the legal protection of anti-employment discrimination from three links: legislation, law enforcement and judicature in order to find a solution to this problem. The author hopes that phenomenon of gender discrimination in women's employment can be fundamentally improved and women's labor rights and interests can be fully protected. In the future, women can really realize their own value in all walks of the society to give a full play of their roles.

\section{AUTHORS' CONTRIBUTIONS}

This paper is independently completed by Kexin Sun.

\section{ACKNOWLEDGMENTS}

I appreciated the professor Richard for his help and guidance in this paper. I learned a lot about equality law and further deepened my interest in law.

I also appreciated my teacher Alisa Wang for her help through the writing of this paper.

Finally, I would like to thank all the teachers, friends and family members for their care and help.

\section{REFERENCES}

[1] Li Bingan, Equal right to work of both sexes and its remedy [J] Journal of Fujian Normal University (philosophy and social sciences), 2007(06): 101107.

[2] Jin Ye, On the principle of non-discrimination in international human rights law -- a study based on women s right to employment security [J] Journal of Jinhua Institute of Vocational Technology, 2012, 12(02):66-70.

[3] National Bureau of Statistics of the People's Republic of China, China Statistical Yearbook [M] Beijing, China statistics publishing house, 1992:116.

[4] National Bureau of Statistics of the People's Republic of China, China Statistical Yearbook [M] Beijing, China statistics publishing house, 1995:98.

[5] Equal Pay Act, 1963.

[6] The Convention on the Elimination of All Forms of Discrimination against Women,1979.

[7] Ma. Del. Mar Serna Calvo, Legislation on women's employment in Latin America [J] A Comparative Study, 1996, 2, p6.

[8] Ma Yongtang, ILO labor standards and enforcement mechanisms on prohibition of discrimination in employment and occupation [J] Chinese labor, 2008(11): 36-39. 
[9] Sun Xiaomei, Legal Protection of women's right to equal employment [D] Jilin University, 2014.

[10] Xia Diya.Wu Puer, Women Employment Discrimination under the perspective of international human rights law [D] Xinjiang University, 2015.

[11] Ian G. Helps \& Patricia M. Skitmore, Discrimination against women in employment, 1975, 8(1), 0-13. 